\title{
The Influence of Destination Image on Tourist Intention and Decision to Visit Tourist Destination (A Case Study of Pemuteran Village in Buleleng, Bali, Indonesia)
}

\author{
Ni Wayan Marsha Satyarini ${ }^{1 *}$, Myrza Rahmanita $^{2}$, Sakchai Setarnawat ${ }^{3}$ \\ 1,2Sekolah Tinggi Pariwisata Trisakti \\ ${ }^{3}$ Burapha University \\ *wayanmarsha@gmail.com
}

\begin{abstract}
This study examines the effects of the destination image to tourist intention and decision to visit tourism destination in Pemuteran Village, Bali. Destination image is an independent variable, tourist intention to visit serves as an intervening variable and decision to visit is a dependent variable. Explanatory research with quantitative method is employed. The number of sample is 112 respondents. Purposive sampling techniques is applied with criteria of Pemuteran village tourists. Data are collected with questionnaires and processed with path analysis. These results indicate that the variable destination image has a direct and significant effect on tourist intention to visit by $11.3 \%$. Variable destination image has a direct and significant influence on the decision to visit by $37.5 \%$. Variable tourist intention to visit has been direct and significant influence on the decision to visit amounted to $16.2 \%$. Based on these results, Pemuteran village should keep trying to build a positive image and to improve the communication between the local government and local communities to strengthen cooperation to improve the natural environment in Pemuteran village.
\end{abstract}

Keywords: destination image, intention to visit, and decision to visit

TRJ Tourism Research Journal, Volume 1 (1), 2017 
The Influence of Destination Image to Tourist Intention and Decision to Visit Tourism Destination (A Case Study of Pemuteran Village in Buleleng, Bali, Indonesia)

\section{A. Introduction}

Tourism is proven to have significant roles in various sectors. First, tourism sector has contributed significantly to the increase of foreign exchange and employment. Besides, this sector also has an impact on the social, economic, and preservation and environmental management, natural resources, and culture. In addition, the tourism activity has affected the development process and the development of certain regions with tourism potential. More important than that, this activity also plays a major role in contributing to the revenue of a region or community. In short, tourism activity is able to increase and foster the development of social, economic society, preservation culture, customs, and sustainability of tourism itself. To be specific, economic sector gets serious attention due to the tourists' needs to spending money. Those tourists' necessities have deeply affected the local community that will directly involve to provide the tourists' needs such transportation, services, attractions, facilities and so forth. Therefore, it can be said that financial income in this sector is one of the purposes of tourism development. (Batmanlussy, 2015, p.2).

Indonesia is endowed with abundant natural potentials for tourism.

The diversed flora and fauna serves as Diversity of Indonesia's natural beauty of flora and fauna that are giving many the main attraction for domestic tourists and foreign tourists to visit. Indonesia has 17,508 islands 6,000 of which were not inhabited, and the third longest coastline in the world after Canada and the European Union. Central Bureau of Statistics Indonesia declared one of famous destination in Indonesia is Bali Island. The image of Bali Island is art, religion, culinary, kindness of the people, culture, beaches, mountains, lakes, fields, the beauty of the underwater coral, to places for shopping and nightlife. On 2002 and 2005, the image of Indonesia on internationally significantly dropped and had negative impact because of terrorist bombing attack in Bali Island, from peaceful island turned into unsafe island to visit, but the image of Bali Island about the beauty of nature and culture is still strong to attract local and foreign tourists to make decision to visit Indonesia, especially to Bali Island until these days.

One of the best destination underwater coral and beach in Bali is Pemuteran Village, unlike the beaches in the area of South Bali, Pemuteran Bay tend to be quieter. Pemuteran village is one of much community-based tourism in Bali that they've won an international level on their coral reef conservation, assisted by local communities and modern technology. Pemuteran village is has been named as one of the top destinations Asia 2016 ranked 7th by Lonely Planet. (nationalgraphic.co.id, 2016)

It is known that the destination image is very an important destinations in the tourism sector, negative or positive. A destination image is 'the expression of all objective knowledge, impressions, prejudice, imaginations, and emotional thoughts an individual or group might have a particular place (Lawson \& BaudBovy, 1977, cited in Jenkins, 1999, p. 1). Govers and Go (2007, cited in 
The Influence of Destination Image to Tourist Intention and Decision to Visit Tourism Destination (A Case Study of Pemuteran Village in Buleleng, Bali, Indonesia)

Sonnleitner, 2011, p.10) declared “As tourism services are intangible, images become more important than reality". Images are very crucial as they reflect the representation of the area into the minds of potential tourists and give them a pre-sense of objectives (Hunt, 1975). Mayo (1975, p. 15) also declared the image of a destination area is a critical factor in a tourist's destination choice process. Weather an image is a true representation of what any given region has to offer to the tourist is less important than the mere existence of the image in the mind of the person. As a decision maker to act on his own image, beliefs, and perceptions of the objectives and not the real situation of the objective of its destination (Hunt, 1975) image of the tourist destination is important because it affects both decision-making behavior of prospective tourists (Mayo, 1973; Crompton, 1979).

The purpose of this research is to explore further on "Is there any significance Influence of Destination Image to Tourist Intention and Decision to Visit Tourism Destination?" The research was conducted with the following objectives:

1. To analyze the significant influence between destination image to tourist intention to visit tourism destination in Pemuteran village, Buleleng, Bali.

2. To analyze the significant influence between destination image to tourist decision to visit tourism destination in Pemuteran village, Buleleng, Bali.

3. To analyze the significant influence between tourist intention to visit to tourist decision to visit tourism destination in Pemuteran village, Buleleng, Bali

\section{B. Literature Review}

\section{Destination Image}

According Echner and Ritchie (1991, cited in Jorgensen, 2004, p.13) as the destination image is "impression of the place" or "perception area". Then according to Hunt (1975, cited in Jorgensen, 2004, p.13) describe that a positive destination image generating increasing visits and have a major impact on tourists.

The image of the tourist destination determines the fundamental role in the success of a tourist destination. This is because the image of a tourist destination member have multi-dimension effect both local and tourists. Perceptions of the image of a tourist destination affect the satisfaction and intent to visit related sites in the future, which of course depends on the ability of the tourist destination to provide an unforgettable positive experience gained during the tour (Beerli and Martin, 2004)

According Echner and Ritchie (cited in Jorgensen, 2004, p.13) Destination image is defined not only as an attribute of destination but also an overall impression that is displayed by the destination. Destination image consists of functional characteristics concerning the real aspects of the 
The Influence of Destination Image to Tourist Intention and Decision to Visit Tourism Destination (A Case Study of Pemuteran Village in Buleleng, Bali, Indonesia)

destination and psychological characteristics concerning aspects of intangibles. Besides the destinations image may be regulated continuum ranging from characteristics that can be used to compare all unique destination to be very little.

Lawson and Baud Bovy (1977, cited in Lopes, 2011, pp.307-308) defines the concept of Destination image as an expression of objective knowledge, prejudices, imagination and emotional thoughts an individual or group about a particular location. Then Kotler, Haider and Rein (1993, cited in Lopes, 2011, pp.307-308) defines image as the sum of all beliefs, ideas and impression that one associated with a destination.

Lopes (2011, p.307) wrote the latest guidelines for tourism marketing recognizes that the development of the image of tourist destinations based on consumer rationality and emotionality, and as a result of a combination of two main components or dimensions, namely:

1. Perceptual and Cognitive image

The main intentions and the given value of each attribute Destination. In other words, the image of Destination is evaluated by the resources and attraction (Stabler, 1995) which will motivate someone to visit a tourism destination (Alhemoud \& Armstrong, 1996; Schneider \& Sonmez, 1999; Gallarza, Saura \& Garcia, 2002; Beerli \& Martin 2004; Govers \& Go, 2005). According to Artuger et al (2013, p.131) cognitive aspects of destination are:

a. Natural Attractions

These attraction are completely natural and include mountains, rivers, lake, national parks, beaches, desert and anything which has not been made by man (Cooper et al, 2005).

b. General Infrastructure

The infrastructure related to the needs of people who aim to help expedite the economy (Wahab, 1992, cited in Yoeti, 1996, p. 192).

c. Atmosphere

The pervading tone or mood of a place, situation, or work of art (Oxford Dictionary).

d. Social Environment

The immediate physical and social setting in which people live or in which something happens or develops. It includes the culture that the individual was educated or lives in, and the people and institutions with whom they interact (Barnett \& Casper, 2001).

e. Value for Money

A utility derived from every purchase or every sum of money spent. Value for money is based not only on the minimum purchase price but also on the maximum efficiency and effectiveness of the purchase.

2. Affective image

Refers to feelings and emotions given by the tourism destination (Keller, 1993; Rial et al, 2000; Rial, Garcia \& Varela, 2008). The emotional

TRJ Tourism Research Journal, Volume 1 (1), 2017 
The Influence of Destination Image to Tourist Intention and Decision to Visit Tourism Destination (A Case Study of Pemuteran Village in Buleleng, Bali, Indonesia)

component is also strongly affected by the tourist motivation (Beerli \& Martin, 2004). Affective has 3 dimensions (Coban, 2012, p.227; Artuger et al, 2013, p. 131): captivating destination, exciting destination, and relaxing destination

\section{Tourist Intention to Visit}

Intentions interpreted as the will, desire or joy (Kamisa, 1997, p.370) is something personal intention and is closely linked with the attitude. Intentions and attitudes are fundamental to the prejudices, and intentions are also important in making decisions.

In this case visit intention is a form or manifestation of behavioral intention, according to Simamora (2002, p.153) theoretically behavioral intention is distinguished from the attitude which is defined as a potential tendency to react so it can be explained that the attitude precedes the behavior. This model is based on an approach that suggests that future consumer behavior or consumer forecasting can be done based on what they have said about their intention in buying or making decisions.

Research of Albarq (2014, p.14) says the theory of tourist intention to visit been analogized same intentions with the purchase intention. Purchase intention is the stage the tendency of respondents to act before the decision to buy really implemented. There is a difference between actual purchases and purchase intention. When the actual purchase is a purchase that really made by the consumer, the purchase intention is the intention to do purchase on the next occasion. Although purchase intention which may not be done in the future, but the measure of the intention in the purchase is generally done in order to maximize the prediction of the the actual purchase itself (Kinnear \& Taylor, 1996, cited in Kurniawan, 2007). According to Ariana and Sudiarta, (2006) intention in visiting sites affected by:

1) The desire to visit tourist attractions based on the information obtained from the mass media.

2) The desire to visit tourist attractions based on the story of the family and relatives

3) The desire to visit tourist attractions for curious directly about these sights.

\section{Decision to Visit}

The decision according to Schiffman and Kanuk (2004, p.547) is: "...selection of an option from two or more alternative choices..." and according to Awater (1993, cited in Setiadi, 2003) defined decision-making as an activity to collect information about relevant alternatives and make choices accordingly.

TRJ Tourism Research Journal, Volume 1 (1), 2017 
The theory of the decision to visit the same analogy with purchase decisions, as research conducted by Jalilvand and Samiei (2012, p.12) which equate that decision travelers visiting the same as consumer purchasing decisions. Decision been a process where a visitor assessing and selecting an alternative that is required based on certain considerations.

According to Kotler and Armstrong (2009, p.146) Purchase decision is the stage of the decision process where consumers actually make purchases of products. According to Gilbert $(2011$, p.81) there are two levels of factors that affect a person in the decision making process to visit. The first level of influence includes psychological influences such as perception and learning. The second level of influence includes everything that has developed during the socialization process including group reference and family influences.

According Pitana and Gayatri (2005, p.73) the various factors that influence the decision to purchase or to visit of a tourist are as follows:

1) Characteristics of tourists

Social-economic characteristics such as age, education, income, and previous experience), as well as behavioral characteristics such as motivation, attitudes and values.

2) Awareness of the benefits of traveling and knowledge of the destinations to be visited such as knowing the image of the destination.

3) Overview of trip, covering a distance, length of stay on the area at tourist destination, time and cost constraints, estimates of the risk of uncertainty and level of trust towards travel agency.

4) Excellence of the tourist destination, which include the type and properties of attractions offered, service quality, physical and social environment, political situation, accessibility and local community behavior towards tourists and also the image of the tourist destination.

\section{Relationship between Variables}

1) Relationship between destination image and tourist intention

The destination image became one of the determinant variables on tourist intention. From the theory discussed earlier, that the company's image can be equated with the destination image as well as consumer intentions can be equated with tourist intention. From this relationship Pangki (2016) declared that the better the image of this tourist destination, the intention of tourists to visit will also be higher.

Hypothesis 1: Destination image significantly influence tourist intention to visit Pemuteran village, Buleleng, Bali, Indonesia

2) Relationship between destination image and decision to visit 
The Influence of Destination Image to Tourist Intention and Decision to Visit Tourism Destination (A Case Study of Pemuteran Village in Buleleng, Bali, Indonesia)

Before deciding to travel to the destination, tourists or consumers first attracted to the image of the destination or company. The statement by Kotler and Keller (2009) that the belief in a product or a brand based on the attributes of each consumer will decide to purchase the services of a preferred and desirable, that theory has continuity with the research by Santi (2015) thus it can be concluded that if the image of the destination has a positive image and has been developing well, it could have the effect the tourist decision to make a visit.

Hypothesis 2: Destination image significantly influence decision to visit Pemuteran village, Buleleng, Bali, Indonesia

3) Relationship between tourist intention and decision to visit

After having an overview of the image of the company or a destination, will appear intention of consumers or tourists for making purchasing decisions ortraveling, from all the information that has been obtained and taken the decision to make a purchase or a visit to a destination, from research conducted by Manongko (2011, p.31) states that the buying intention or intention has been a direct and positive influence, on purchasing decisions or decisions visits a destination. From these studies it can be concluded that the higher intention of the consumers of a product or service, the higher the purchasing decisions to be taken.

Hypothesis 3: Tourist intention to visit significantly influence decision to visit Pemuteran village, Buleleng, Bali, Indonesia

\section{Conceptual Framework}

From the theory generator described earlier, and therefore independent variable, intervening, and dependent will be explained as follows:

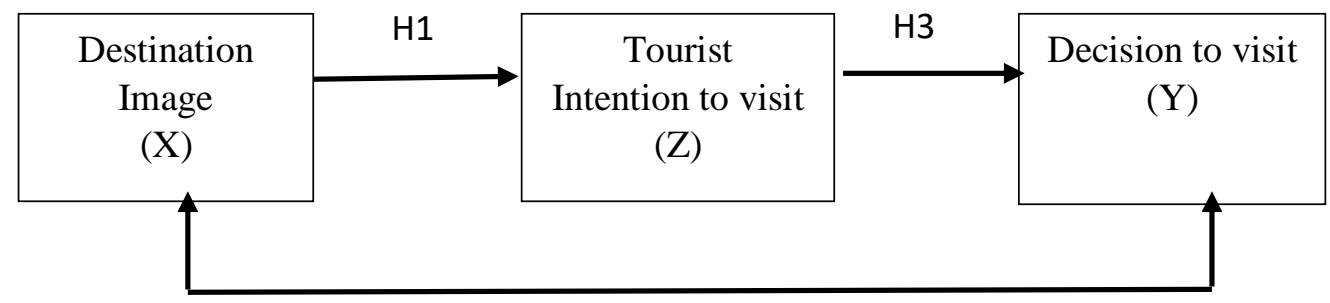

Figure 1. Conceptual framework

Based on the theory that has been put forward by experts and research history, then the hypothesis of this study are:

H1: Destination image significantly influence tourist intention to visit.

H2: Destination image significantly influence decision to visit.

H3: Tourist intention to visit significantly influence decision to visit.

TRJ Tourism Research Journal, Volume 1 (1), 2017 
The Influence of Destination Image to Tourist Intention and Decision to Visit Tourism Destination (A Case Study of Pemuteran Village in Buleleng, Bali, Indonesia)

\section{Research Methodology}

This type of research used in this research is explanatory research with quantitative method. From the previous explanation in this study the variables that will be used, among others:

1. Destination image as independent variable $(\mathrm{X})$

2. Tourist Intention to visit as intervening variable $(\mathrm{Z})$

3. Decision to visit as dependent variable $(\mathrm{Y})$

In this research the population are people who come to Pemuteran village, Buleleng, Bali, Indonesia. Sampling used in this research is purposive sampling. Determination of the number of samples in this refers to the opinion of Malhotra in (2004, cited in Rahayu, 2005, p.46) the number samples taken can be determined by multiplying the minimum sub-variable to 5 . Referring to the minimum sample to be taken that the study used a sample of 150 respondents were obtained from 30 indicators multiplied by 5 . The number of samples will exceeded $10 \%$ as an anticipation factor and total sample will be 165 respondents (Octavia, et al, 2015).

In this research will be to test the validity and reliability by taking a small sample using 30 respondents. If an item or questions that do not pass or valid in this test, then the item or the question can be removed or repaired intent sentence structure and method of data analysis to be used are:

1. Normality Distribution test

Normality test data will used to examine is the Kolmogorov-Smirnov test (Chakravart, Laha, and Roy, 1967) is used to determine the distribution of the sample data. Testing criteria with a view scale Kolmogorov-Smirnov test is;

a. If the significance of $>0.05$ meaning the data is normally distributed.

b. If significance $<0.05$ meaning the data are not normally distributed

2. Path Analysis

The significance of the model looks based on the beta coefficient $(\beta)$ which is significant to the path as below:

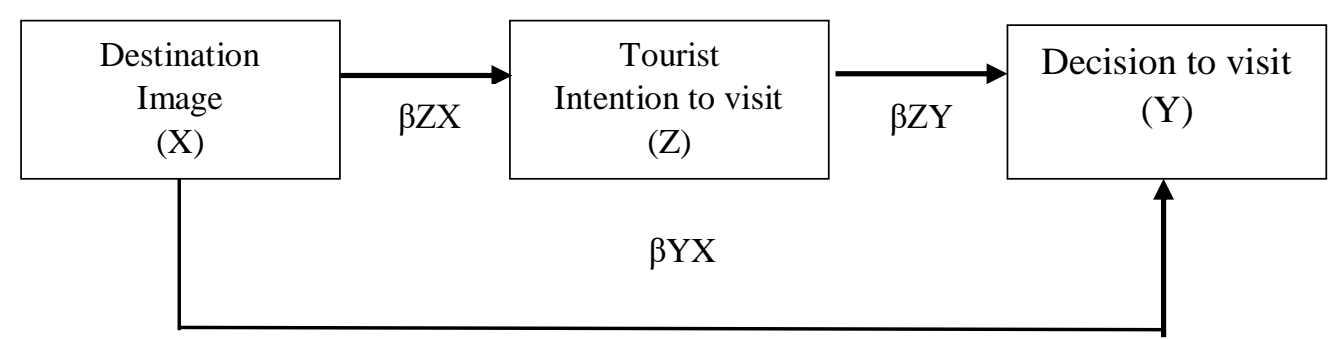

Figure 2. Path Analysis

Model path analysis were used in this study can be described in structuralequation as follows:

TRJ Tourism Research Journal, Volume 1 (1), 2017 
The Influence of Destination Image to Tourist Intention and Decision to Visit Tourism Destination (A Case Study of Pemuteran Village in Buleleng, Bali, Indonesia)

3. T-test

$$
\begin{aligned}
& \mathrm{TI}=\beta_{0}+\beta_{1} D I+\varepsilon_{1} \ldots \ldots \ldots \ldots \ldots \ldots \ldots \ldots \ldots .(\text { Equation } 1) \\
& \mathrm{DV}=\beta_{0}+\beta_{1} D I+\beta_{2} T I+\varepsilon_{2} \ldots \ldots \ldots \ldots \ldots \ldots .(\text { Equation } 2)
\end{aligned}
$$

$\mathrm{T}$ test is a test of significance intended to determine whether there is a significant or no relationship between these variables (Prayitno, 2012, p.109). T-test formulation hypothesis:

1) $\mathrm{HO}: \boldsymbol{b} \boldsymbol{i}=0, \vec{i}=1$

$\mathrm{H} 0$ accepted and $\mathrm{Ha}$ rejected, it means there is no partial effect between the independent variable $(\mathrm{X})$ and dependent variable $(\mathrm{Y})(0,05 \leq$ Sig $)$

2) Ha: $b \vec{i}=0, \vec{i}=1$

$\mathrm{H} 0$ rejected and $\mathrm{Ha}$ accepted, it means there is a partial effect between the independent variable $(\mathrm{X})$ and dependent variable $(\mathrm{Y})(0,05 \geq$ Sig $)$

4. Determination Coefficient $\left(\mathrm{R}^{2}\right)$

This analysis is used to determine the proportion of independent variables $(\mathrm{X})$ in contributing to the dependent variable $(\mathrm{Y})$ and the calculation result of this analysis in the form of percentage (Santoso, G.H., 2011, p. 53).

5. Path calculation

Path calculation on this study are: Calculating direct effect (DE), Calculating indirect effect (IE), and Calculating the total effect (TE).

\section{Result and Discussion}

The questionnaires had been distributed to respondents with 165 total of questionnaires. The total of questionnaire had been collected was 123 questionnaires. On the process of calculating the data, there was 11 questionnaires were not useable to fit this research. The final questionnaires that used in this research are 112 questionnaires. Results of hypothesis testing in this

\begin{tabular}{|c|c|c|}
\hline \multicolumn{3}{|c|}{ Normality Test Results } \\
\hline & & $\begin{array}{c}\text { Unstandardized } \\
\text { Residual }\end{array}$ \\
\hline $\mathrm{N}$ & & 112 \\
\hline Normal Parameters ${ }^{\mathrm{a}, \mathrm{b}}$ & Mean & .0000000 \\
\hline & Std. Deviation & 1.63066863 \\
\hline Most Extreme Differences & Absolute & .056 \\
\hline & Positive & .044 \\
\hline & Negative & -.056 \\
\hline Test Statistic & & .056 \\
\hline Asymp. Sig. (2-tailed) & & .320 \\
\hline
\end{tabular}
research are:

1. Normality Distribution test

TRJ Tourism Research Journal, Volume 1 (1), 2017 
The Influence of Destination Image to Tourist Intention and Decision to Visit Tourism Destination (A Case Study of Pemuteran Village in Buleleng, Bali, Indonesia)

The result is Asymp. Sig (2-tailed) or probability value has a value of $0.320>$ 0.05 and this indicates that the data is normally distributed.

2. Path Analysis

Result of path analysis test between independent variables as destination image, intervening variables as tourist intention to visit and dependent variables as decision to visit, can be seen in result below:

\begin{tabular}{|c|c|c|c|c|c|c|}
\hline \multicolumn{2}{|c|}{ Standardized } & $t_{\text {value }}$ & Sig. & $\alpha$ & Result & $\mathrm{R}^{2}$ \\
\hline Path & $\operatorname{Beta}(\beta)$ & & & & & \\
\hline $\begin{array}{l}\mathrm{DI} \rightarrow \\
\mathrm{TI}\end{array}$ & 0.336 & 4.041 & 0.000 & $<0.05$ & Significant & 0.113 \\
\hline $\begin{array}{l}\mathrm{DI} \rightarrow \\
\mathrm{DV}\end{array}$ & 0.612 & 8.335 & 0.000 & $<0.05$ & Significant & 0.375 \\
\hline $\begin{array}{l}\mathrm{TI} \rightarrow \\
\mathrm{DV}\end{array}$ & 0.403 & 4.805 & 0.000 & $<0.05$ & Significant & 0.162 \\
\hline
\end{tabular}

The result of the equation to be done are:

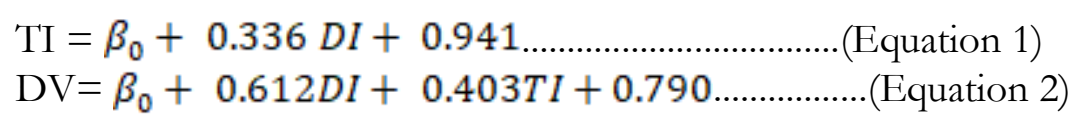

1) Influence of Destination Image (DI) to Tourist Intention to Visit (TI) The signification of DI to TI is $0.000<0.05$. This indicates that the DI has a positive and significant effect on the TI. $\mathrm{R}^{2}$ amounted 0.113 which can be concluded that the effect of destination image to tourist intention amounted $11.3 \%$.

2) Influence of Destination Image (DI) to Decision to Visit (DV)

The signification of DI to DV is $0.000<0.05$. This indicates that the DI has a positive and significant effect on the DV. t $\mathrm{R}^{2}$ amounted 0.375 which can be concluded that the effect of destination image to tourist intention amounted $37.5 \%$.

3) Influence of Tourist Intention to Visit (TI) to Decision to Visit (DV) The signification of TI to DV is $0.000<0.05$. This indicates that the DI has a positive and significant effect on the DV. $\mathrm{R}^{2}$ amounted 0.162 which can be concluded that the effect of destination image to tourist intention amounted $16.2 \%$. 
The Influence of Destination Image to Tourist Intention and Decision to Visit Tourism Destination (A Case Study of Pemuteran Village in Buleleng, Bali, Indonesia)

3. t-Test

The first stage is to find the degree of freedom (df) using the formula for simple regression with one independent:

$$
\begin{aligned}
& \mathrm{df}=\mathrm{n}-2 \\
& \mathrm{df}=112-2 \\
& \mathrm{df}=110
\end{aligned}
$$

The result of degree of freedom (df) is 110 , from $T$ distribution table that $t_{\text {table }}$ is 1.982. Based on the results obtained by t-test results can be stated:

1) The influence of destination image to tourist intention to visit

The results obtained $t_{v a l u e}>t_{\text {table }}$ with result of $4.041>1.982$ and significance of $0.000<0.05$, then it can be concluded that $\mathrm{H} 0$ is rejected and $\mathrm{Ha}$ is accepted. Which means there is partial effect between destination image and tourist intention to visit.

2) The influence of destination image to decision to visit

The results obtained $\mathrm{t}_{\mathrm{value}}>\mathrm{t}_{\text {table }}$ with result of $8.335>1.982$ and significance of $0.000<0.05$, then it can be concluded that $\mathrm{H} 0$ is rejected and $\mathrm{Ha}$ is accepted. Which means there is partial effect between destination image and decision to visit.

3) The influence of tourist intention to visit to decision to visit

The results obtained $t_{\text {value }}>t_{\text {table }}$ with result of $8.335>1.982$ and significance of $0.000<0.05$, then it can be concluded that $\mathrm{H} 0$ is rejected and $\mathrm{Ha}$ is accepted. Which means there is partial effect between tourist intention to visit to decision to visit.

4. Determination Coefficient $\left(\mathrm{R}^{2}\right)$

The value of the total determination coefficient in this study is obtained through:

1) $\varepsilon_{1}$ equation 1 (other variables part from DI to TI):

$\varepsilon_{1}=\sqrt{1-R_{1}^{2}}$

$\varepsilon_{1}=\sqrt{1-0.113}$

$\varepsilon_{1}=\sqrt{0.887}$

$\varepsilon_{1}=0.941$ or $94.1 \%$

2) $\varepsilon_{2}$ equation 2 (other variables part from DI to DV):

$\varepsilon_{2}=\sqrt{1-R_{2}^{2}}$

$\varepsilon_{2}=\sqrt{1-0.375}$

$\varepsilon_{2}=\sqrt{0.625}$

$\varepsilon_{2}=0.790$ or $79 \%$

3) Total determination coefficient $\left(R^{2}\right)$ :

$R^{2}=1-\left(\varepsilon_{1}^{2} \times \varepsilon_{2}^{2}\right)$

$R^{2}=1-\left((0.941)^{2} \times(0.790)^{2}\right)$

$R^{2}=1-(0.885 \times 0.624)$

TRJ Tourism Research Journal, Volume 1 (1), 2017 
The Influence of Destination Image to Tourist Intention and Decision to Visit Tourism Destination (A Case Study of Pemuteran Village in Buleleng, Bali, Indonesia)

$R^{2}=1-0.552$

$R^{2}=0.448$ or $44.8 \%$

$\mathrm{R}^{2}$ value of total is 0.448 , meaning decision to visit variable is explained by destination image with tourist intention to visit as intervening variable equal to $44.8 \%$ and the rest of $55.2 \%$ is explained other factors outside research model.

5. Path calculation

1) Direct effect (DE)

i. The direct effect of destination image $(\mathrm{X})$ to tourist intention to visit $(\mathrm{Z})$ $\mathrm{R}^{2}$ amounted 0.113 , and the signification of DI to TI is $0.000<0.05$. This indicates that the DI has a positive and significant effect on the TI.

ii. The direct effect of destination image $(\mathrm{X})$ to decision to visit $(\mathrm{Y}) \mathrm{R}^{2}$ amounted 0.375 , and the signification of DI to DV is $0.000<0.05$. This indicates that the DI has a positive and significant effect on the DV.

iii. The direct effect of tourist intention to visit $(\mathrm{Z})$ to decision to visit $(\mathrm{Y})$ $\mathrm{R}^{2}$ amounted 0.162 , and the signification of TI to DV is $0.000<0.05$. This indicates that the TI has a positive and significant effect on the DV.

2) Indirect effect (IE)

Indirect influence is a situation where the independent variable influences the dependent variable through another variable called intervening variable. The effect of destination image $(X)$ to tourist intention to visit $(\mathrm{Z})$ and decision to visit $(\mathrm{Y})$ is:

$\mathrm{X} \rightarrow \mathrm{Z} \rightarrow \mathrm{Y}=0.612 \times 0.336 \times 0.403=0.083$

Can be concluded that he effect of destination image $(X)$ to tourist intention to visit $(\mathrm{Z})$ and decision to visit $(\mathrm{Y})$ has a regression coefficient of 0.083 .

3) The total effect (TE)

Total effect is the sum of direct effects and indirect effects, with formulation:

$$
T E_{Y Z X}=D E_{X Y 2}+I E_{Y Z X}
$$

i. The influence of destination image to decision to visit, the total is:

$\mathrm{TE}=0.375+0.083$

$\mathrm{TE}=0.818$

ii. The influence of tourist intention to visit to decision to visit, the total is:

$\mathrm{TE}=0.162+0.083$

$\mathrm{TE}=0.245$

TRJ Tourism Research Journal, Volume 1 (1), 2017 
The Influence of Destination Image to Tourist Intention and Decision to Visit Tourism Destination

(A Case Study of Pemuteran Village in Buleleng, Bali, Indonesia)

The complete results of path analysis in this study can be explained in detail the influence and relationship between research variables in figure 3 below:

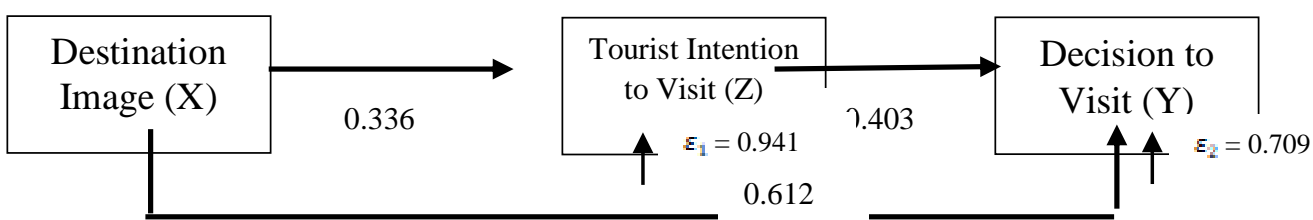

Figure 3. Path Analysis Results

\section{E. Conclusion}

Based on the description in the preceding chapter, especially in analysis and discussion, the following conclusions can be drawn:

1. Influence of destination image to tourist intention to visit

There is a significant positive effect of destination image variable on tourist intention to visit. Destination image has a significant influence on tourist intention to visit, with the path coefficient of $(\beta)$ of 0.336 . The better the image Pemuteran village will have an impact on increasing tourist intention to visit Pemuteran village.

From the research that has been conducted in Pemuteran village, it can be concluded that the local community and local government always maintain the existing image, i.e. maintaining nature conservation, always make sure their give the best hospitality to the tourist, maintaining their culture heritage and maintaining the destination with balinese ambiance although Pemuteran village image is worldwide. The better the image of a destination, the more positive information that tourists receive through the media or relatives and friends and will cause a great desire to have interest to visit a destination. The results of this study together with the theory expressed by Pangki (2016) declared that the better the image of this tourist destination, the intention of tourists to visit will also be higher.

2. Influence of destination image to tourist decision to visit

There is a significant positive effect of destination image variable on tourist decision to visit. Destination image has a significant influence on tourist decision to visit, with the path coefficient of $(\beta)$ of 0.612 . The better the image of Pemuteran village will have an impact on increasing tourist decision to visit Pemuteran village. From previous explanation, the images offered by each destination are different, based on the circumstances and situation of the destination itself and which ultimately attract different market segments. From this image can be seen from the demographic of the tourist who

TRJ Tourism Research Journal, Volume 1 (1), 2017 
The Influence of Destination Image to Tourist Intention and Decision to Visit Tourism Destination (A Case Study of Pemuteran Village in Buleleng, Bali, Indonesia)

decide to come, what advantages for them when deciding to visit, and how the level of excellence of the destination if tourists decide to visit.

The results of this study together with the theory expressed by Kotler and Keller (2009) that the belief in a product or a brand based on the attributes of each consumer will decide to purchase the services of a preferred and desirable, that theory has continuity with the research by Santi (2015) thus it can be concluded that if the image of the destination has a positive image and has been developing well, it could have the effect the tourist decision to make a visit.

3. Influence of tourist intention to visit to tourist decision to visit

There is a significant positive effect of tourist intention to visit variable on tourist decision to visit. Tourist intention to visit has a significant influence on tourist decision to visit, with the path coefficient of $(\beta)$ of 0.403 . The better the image they received from media or relatives and friends of Pemuteran village will have an impact on increasing tourist decision to visit Pemuteran village.

The results of this study together with the theory expressed by by Manongko (2011, p.31) states that the buying intention or intention has been a direct and positive influence, on purchasing decisions or decisions visits a destination. From these studies it can be concluded that the higher intention of the consumers of a product or service, the higher the purchasing decisions to be taken.

Here are suggestions that can be realized by the destination and further research:

1. Pemuteran village is a destination that has a great image and positive from the point of view of the community and tourists. Pemuteran village is advised to keep trying to build a positive image that can be achieved with responsibility to the surrounding environment because the tourism in Pemuteran village built because of the natural beauty on land and the seabed. With these actions can continue to build a better image for the point of view from the tourists.

2. The need for improve the communication between the local government and local communities to strengthen cooperation to improve the natural potential of Pemuteran village, because there are some conservation related to nature, especially related to conservation of sea turtles is still built by the local community without assistance from the local government by doing so Pemuteran village image development will become better if the relationship between government and society is also getting better.

3. For future research, is expected to conduct research with the right time that is in high season time because the results will be obtained will be more leverage. In further research can be focused on marketing communications and tourist behavior for more in-depth research.

TRJ Tourism Research Journal, Volume 1 (1), 2017 
The Influence of Destination Image to Tourist Intention and Decision to Visit Tourism Destination (A Case Study of Pemuteran Village in Buleleng, Bali, Indonesia)

In this study there are some limitations of research, among others as follows:

1. The research period used in this study is relatively short from May to June 2017, which is known that the month is still the low season for tourists come to Pemuteran village.

2. Research involves a limited number of research samples with a total of 112 respondents, so the results can not be generalized to large groups of samples.

The existence of limited research by using questionnaire is sometimes the answer given by the sample does not show the real situation and does not answer in full questionnaire

\section{F. Acknowlegement}

I would express my sincere appreciation to my thesis advisors Prof. Dr. Sakchai Setarnawat, Dr. Myrza Rahmanita and Dr. Kanvalai Nontakaew Ferry for continuous support of the thesis, for the supporting critics, building motivations and life lesson that have guided the researcher.

Deep appreciation will also not forgotten to Faculty of Management and Tourism, for giving me a chance to study in Master of International Tourism Management Program at Burapha University. And I also would like to provide my special thanks to. Dean. Prof. Dr. Sakchai Setarnawat, and all of the staffs in Faculty of Management and Tourism for providing helps and always make sure I feel comfortable during my study here.

Without Management of Trisakti Institute of Tourism Indonesia, I would never had a chance to study in joint degree Program in Trisakti Institute of Tourism Indonesia and Burapha University of Thailand. Thank you for granting me for such rare opportunity.

\section{REFERENCES}

Albarq, A. N. (2013). Applying a SERVQUAL model to measure the impact of service quality on customer loyalty among local Saudi banks in Riyadh. American Journal of Industrial and Business Management, 3, 700.

Alhemoud, A.M., \& Armstrong, E.G. (1996). Image of tourism attractions in Kuwait. Journal of travel Research, 34 (4), 76 - 80.

Ariana, N., \& Sudiarta, I.N. (2006). Impliementasi marketing mix pada masingmasing tahap life cycle pariwisata Bali. Journal Manajemen Pariwisata, $6(2), 85-102$.

Artuger, S., \& Kendir, H. (2013). Agritourist motivations: The case of Turkey. International Journal of Business and Management, 8 (21), 63 - 69. 
The Influence of Destination Image to Tourist Intention and Decision to Visit Tourism Destination (A Case Study of Pemuteran Village in Buleleng, Bali, Indonesia)

Barnett, E., \& Casper, M. (2001). A definition of "social environment". American Journal of Public Health, 91 (3), 201 - 214.

Batmanlussy, E. (2015). Analisis strategi pengembangan objek wisata di kabupaten Maluku Tenggara Barat. Master's thesis, Department of Economy, University of 17 Agustus 1945, Surabaya.

Beerli, A., \& Martín, J.D. (2004). Factors influencing destination image. Annals of Tourism Research, 31 (3), 657 - 681.

Chakravart, N. L., \& B. Roy. (1967). Handbook of methods of applied statistics. New York: John Wiley and Sons.

Coban, S. (2012). The effects of the image of destination on tourist satisfaction and loyalty: The case of Cappadocia. European Journal of Social Science, 29 (2), 222 - 232.

Cooper, Chris., et al. (2005). Tourism principles \& practice. United Kingdom: Longman Group Limited.

Crompton, J. (1979). Motivations for pleasure vacation. Annals of Tourism Research, 6 (4), 408 - 424.

Gallarza, M, et al. (2002). Destination image: Towards a conceptual framework. Annals of Tourism Research, 29 (1), $56-78$.

Gilbert, D. (2011). Buried by bad decisions. Nature International Weekly Journal of Science, 474, $275-277$

Govers, R., Go, F.M. \& Kumar, K. (2007). Promoting tourism destination image. Journal of Travel Research, 46 (1), 15-23.

Hunt, J.D. (1975). Image as a factor in tourism development. Journal of Travel Research, 13, $1-7$.

Jalilvand, M.R., \& $\underline{\text { Samiei, }}$ N. (2012). The effect of electronic word of mouth on brand image and purchase intention: An empirical study in the automobile industry in Iran. Marketing Intelligence \& Planning, 30 (4), $460-476$.

Jenkins, O.H. (1999). Understanding and measuring tourist destination images. International Journal of Tourism Research, 1 (1), 1 - 15.

Jorgensen, L. (2004). An analysis of a destination's image and the language of tourism. Bachelor's thesis, The Aarhus School of Business. Retrieved from http://pure.au.dk/portal-asb-student/ files/2156/000134297134297.pdf

Kamisa. (1997). Kamus lengkap bahasa indonesia. Surabaya: Kartika.

Keller, K. L. (1993). Conceptualizing, measuring and managing customer-based brand equity. Journal of Marketing, 57 (1), 1 - 22.

Kotler,P. \& Amstrong, G. (2009). Prinsip-prinsip pemasaran. Jakarta: Erlangga.

Kotler, P. \& Keller, K.L. (2009). Manajemen pemasaran. Jakarta: Erlangga.

Kurniawan, et al. (2007). Analisis faktor-faktor yang mempengaruhi minat beli ulang produk serta dampaknya terhadap loyalitas pelanggan (studi kasus pada produk sakatonik liver di kota Semarang). Journal Studi Manajemen ぬ Organisasi, 4 (2), 20 - 29.

TRJ Tourism Research Journal, Volume 1 (1), 2017 
The Influence of Destination Image to Tourist Intention and Decision to Visit Tourism Destination (A Case Study of Pemuteran Village in Buleleng, Bali, Indonesia)

Lopes, S.D.F. (2011). Destination image: Origins, developments and implications. Revista de Turismo y Patrimonio Cultural, 9 (2), 305 - 315.

Manongko, A. A. (2011). Green marketing dan pengarubnya terhadap keputusan pembelian melalui minat membeli produk organik. Master's thesis, Faculty of Economy and Business, University of Brawijaya.

Nationalgraphic.com. (2016). Desa Pemuteran Bali masuk daftar destinasi top Asia 2016. Retrieved from http://nationalgeographic.co.id/berita/2016/07/desa-pemuteran-balimasuk-daftar-destinasi-top-asia-2016

Octavia, D., et al. (2015). Analisis beban emisi co dan ch4 dari kegiatan pembakaran sampah rumah tangga secara terbuka (studi kasus kecamatan sungai Kakap, Kabupaten Kubu Raya). Retrieved from http://download.portalgaruda.org/

Pangki, R. (2016). Pengaruh citra destinasi terhadap kepuasan wisatawan dan intensi berkunjung pada wisata pulau Pamutusan Sumbar. Bachelor's thesis, Faculty of Economy, Andalas University, Indonesia.

Pitana, I.G., \& Gayatri, P.G. (2005). Sosiologi pariwisata. Yogyakarta: Andi.

Priyatno, D. (2010). Teknik mudah dan cepat melakukan analisis data penelitian dengan spss dan tanya jawab ujian pendadaran. Yogyakarta: Gaya Media.

Rahayu, S. (2005). Aplikasi SPSS versi 12.00 dalam riset pemasaran. Bandung: Alfabeta.

Santi. (2015). Pengaruh citra destinasi kebun raya Cibodas sebagai destinasi wisata alam terhadap keputusan berkunjung. Bachelor's thesis, Faculty of Social Science Education, University of Pendidikan Indonesia.

Schiffman \& Kanuk. (2004). Perilaku konsumen (7th ed). Jakarta: Prentice Hall. Schneider, L., \& Sönmez, S. (1999). Exploring the tourist image of Jordan. Tourism Management, 20, 539 - 542.

Setiadi, N.J. (2003). Perilaku konsumen: Konsep dan implikasi untuk strategi dan penelitian pemasaran. Jakarta: Kencana.

Simamora, B. (2002). Panduan riset perilaku konsumen. Jakarta: Gramedia.

Sonnleitner, K. (2011). Destination image and its effects on marketing and branding a tourist destination (A case study about the austrian national tourist office with a focus on the market sweden). Master's Dissertation, Master of Science in Tourism Studies, School of Business Studies, Södertörn University.

Stabler, W.J. (1995). The image of destination regions: theoretical and empirical aspects. Marketing in the Tourism Industry: the Promotion of Destination Regions, (pp. 133 - 161). London: Croom Helm.

Yoeti, O.A. (1996). Pengantar ilmu pariwisata. Bandung: Angkasa. 